\title{
Narratives of the Dispossessed and Casteless: Politics of Land and Caste in Rajarhat, West Bengal
}

\author{
Dr. Ritanjan Das \\ Faculty of Business and Law, University of Portsmouth
}

\begin{abstract}
This article examines the political narrative around a two-decade old process of land acquisition and development in the 'global city' Rajarbat, a former rural settlement in the Indian state of West Bengal. The narrative - exploring the development politics in Rajarbat - is built against the backdrop of a neoliberal state in the Global South acting as a corporate facilitator, particularly in matters of 'land', and the concomitant dispossession. The multifaceted politics of Rajarbat takes shape in contrast to the erstwhile communist regime in West Bengal, the dichotomy of a Left state engaged in forceful and violent land acquisition thus forming an interesting paradox. The paper also presents evidence against the long held political myth of caste-relations being irrelevant in Bengali politics, by examining the upper-caste dominated social relations in Rajarhat and the formation of low-level cartels or 'syndicates' in the area. In conclusion, the article points to the reinvention and redeployment of caste relations - even in increasingly urban spaces where 'hierarchical' caste practices are usually taken to be on the decline - rooted in the duality between land-struggles and development.
\end{abstract}

Keywords: Rajarbat, West Bengal, CPIM, land acquisition, displacement, caste.

\section{Introduction}

In contemporary India, land is arguably one of the biggest sites of struggle. With changing patterns of land ownership and a steady rise in associated displacement, the economic opportunities for the newly landless are becoming increasingly rare. Even if land is acquired for special economic zones (SEZs) or industries, the dispossessed hardly find employment in such ventures (Gardner et al, 2012). What awaits those with the least social capital and opportunities instead is increasing immiseration for the sake of vast profits for the privileged, almost always resulting in a heightened social and economic inequality (Gardner and Gerharz, 2016).

Displacement from land and concomitant dispossession of economic and social capital, however, is hardly new in India. Starting from the rarely accountable land encroachment during colonial times and the Nehruvian project of nation building post-independence, land acquisitiondisplacement continues to remain all too familiar till date. There is ongoing dispossession of farmers induced by state-sponsored property speculation and business interests (ibid.) in many forms: SEZs (Levien, 2012, 2013; Cross, 2014), large scale mining projects (Padel and Das, 2010), conservation (Münster and Münster, 2012), agribusiness, housing, and industrialisation (Nielsen, 2018; Nielsen and Oskarsson; Akram-Lodhi, 2009). In fact, as Cernea (2016) recently estimated, close to 100 million people are likely to have been displaced since independence. 
There are of course wider forces at play here: the restructuring of political economies across the Global South, the debt crises, the advent of neoliberalism, etc. Among the far reaching upshots of these transforming forces, one of the most notable has been the reconstruction of the 'urban' as a crucial and strategic site for the unfolding of global and national scale projects, along with a concomitant reduction of perceived value of the rural (Roy, 2002; 2005; Sassen, 2006). As widely observed in urbanisation research, the global city discourse has found a strong foothold in the Global South, instrumental in remaking the urban in the image of the global (i.e. the West) (Mahadevia, 2008). At the same time, it is also important to acknowledge that the 'global city' approach takes the urban as a site where there is a convergence of capital, people, information, goods and services. But cities in the Global South often lags far behind in such processes of efficient convergence. The notion of 'urban development' thus creates a false convergence between the so-called First and Third-world cities, focusing predominantly on the global actors/agencies instead of understanding the local actors, conditions, and networks (Chen, Wang, and Kundu, 2009).

It is this dynamic context that provides the backdrop for much of the land struggles in India. With the state strongly promoting capital investment, land occupies the centre-stage, as the new cities, infrastructural initiatives, real-estate all require vast amounts of land. And yet, not only is land of relatively short supply, there are also concerns about state-corporate nexus, corruption, political posturing, an asymmetric economic environment, a deep-rooted and increasing inequality and discrimination. Therefore, as Bedi (2015:596) notes, 'land transfers and acquisitions provide opportunities to scrutinise and contest state action, inaction, or irregularities'. There has indeed been a plethora of studies on how the recent spate of land transfers have led to urban, peri-urban and rural 'land wars', as people threatened with displacement and dispossession mobilised in different ways to retain their land, and negotiated with state agencies for greater compensation or to be made 'partners' in the development processes (Bedi, 2015; Nielsen, 2015).

A similar story unfurls in this paper. It recounts the development of Rajarbat (or Calcutta New Town) in West Bengal, an upmarket satellite township adjacent to the state capital Calcutta (or Kolkata), comprising mostly of business/IT hubs, a slew of luxury real estate, and shopping malls. Albeit seen as a symbol of Calcutta's resurgence from an image of a decaying metropolis, Rajarhat is simultaneously a story of 'continuous cycle[s] of evictions, expropriations, ecological degradation, and social protest' (Bose, 2013:127). Furthermore, the land struggles in Rajarbat have also led to an evolving dichotomy along caste-lines that is particularly intriguing, due to the oftrepeated characterisation that caste is largely irrelevant in Bengal, historically owing to a rather limited electoral aggregation of caste interests (Sinharay, 2012). However, this long-held political myth has recently come under some serious questioning via a series of works demonstrating the deep-rooted embeddedness of caste hierarchies in Bengali politics and land relations (Bandyopadhyay, 2012; Samaddar, 2013; Chatterjee, 2012; Chandra et al, 2015). Drawing on an ethnography in the villages of Rajarhat and archival research, the paper adds to this literature by deconstructing the Rajarhat 'development' story - interrogating both the land struggles and the implicit caste dimensions around the said development.

Before proceeding, a final point needs to be made about the unique socio-political context of the state. Historically, West Bengal was an aberration - an island of political stability - amidst a rather chaotic 
Indian democracy. It was ruled by the Left Front (LF) government, a coalition of Left parties spearheaded by the Communist Party of India-Marxist (CPIM), uninterruptedly from 1977 to 2011. The CPIM/LF regime brought in significant land reforms, was the first in the country to initiate proper democratic decentralisation via panchayati-raj (village democracy), and gained unprecedented popularity as a government for the poor. However, through the 1990s and early 2000s it gradually adopted a more pro-market stance, pursuing a private-capital led industrialisation agenda, which had even led to securing a historic majority in the 2006 state elections. However, the regime went down a path of steady electoral decline soon after, eventually capitulating to the main opposition party Trinamool Congress (TMC) in 2011. And it is precisely in the regime's final term that West Bengal also came to feature prominently in the context of India's new 'land wars', the (in)famous Singur-Nandigram episodes being cases in point (see Nielsen, this volume, and Sarkar and Chowdhury, 2009). Not only did Singur-Nandigram spark nationwide debates about the nature and legality of acquisition under the archaic colonial law of 1894, but they also mark critical junctures in the state's political fortunes and for the Indian Left in general. The LF, having returned to power for an unprecedented $7^{\text {th }}$ consecutive term in 2006, completely collapsed under the crisis that emerged from its high handedness in acquiring farmland for private entrepreneurs in these two hamlets, thereby leading to its subsequent decline. It is this dichotomous backdrop against which the Rajarbat narrative needs to be told, one where private industrialisation and neoliberal urbanism was embraced by a regime having built its political capital as pro-poor and pro-farmer, and in a state that was a bastion of Marxist political forces for over three decades.

The paper is organised as follows: the next section provides a brief theoretical overview of land acquisition induced displacement-dispossession. Section three introduces the Rajarbat story, and section four explores the politics of it, bringing tales of violence, coercion and institutional/legal circumvention to the fore. Section five shifts the focus to the largely overlooked aspects of casteconsciousness in Rajarbat, and examines how such consciousness found new forms of expression in the politics of land struggles, particularly through the formation of low-level cartels or 'syndicates'. By doing so, the paper also hopes to bring to light the rarely recognised analytical linkages between caste and land wars in West Bengal - a state that features prominently in the narratives of 'land wars' in contemporary India (the (in)famous Singur-Nandigram episodes being cases in point, see section 3) - where caste-relations have been historically considered irrelevant.

\section{Theorising Dispossession and Displacement}

Among the most notable effects of contemporary capitalist forces of accumulation across much of the developing world is the structural shift in the value of land towards commodification (Akram-Lodhi, 2007), and the state transforming from an active promoter of public industries to a land-broker for private corporations (Levien, 2013). However, as Gardner and Gerharz (2016:2) rightly point out, while such effects of capitalist accumulation (more sharply observed in the context of neoliberalisation) remain the focus of much of the literature on land, the process of dispossessiondisplacement also needs to be analytically fleshed out, the 'means by which changes of land use and differential access take place and...the varying forms of resistance or compliance by different 
groups and individuals over time.. ${ }^{1}$ In contemporary India/South Asia, for example, dispossession from land displays both a certain continuity and change in comparison to earlier periods (Adnan, 2016). State-led acquisition, albeit age-old, has altered significantly in purpose towards supplying land to private corporations. Moreover, the very notion of dispossession implies a straightforward transfer of rights in which those that once possessed are dispossessed...[but] the local realities...are often far more nuanced, involving complex interrelationships between groups of users, legality, the state' (Gardner and Gerharz, 2016:2). There is thus an evolving discussion about appropriate theoretical frameworks, especially building on Marx's concept of primitive accumulation (1976), and Harvey's (2003) conceptualisation of 'accumulation by dispossession' (ABD), alongside newer perspectives on market-driven processes of dispossession (Akram-Lodhi, 2012), extra-economic coercion (Levien, 2012), non-market transactions (Khan, 2004), and voluntary processes based on persuasion, incentives, and temptation (Adnan, 2016).

What then, conceptually, is an adequate way to make sense of the alarming rate of global loss of land from small holders to large scale businesses (Makki, 2014), and particularly in a South Asian context, the local and historic specificities which allow us to explain its particular trajectories? While it is beyond this paper's purview to go into a detailed theoretical discussion, a useful starting point could be the very notion of 'development' in the Foucauldian sense of 'regimes of truth'. Foucault has discussed the power of discourses, or 'architectures of knowledge' at length, describing how once the world is framed in taken-for-granted ways, the discourses get transformed into unquestionable 'regimes of truth'. The power of such regimes can then produce its own '...reality; it can produce domains of objects and rituals of truth' (Foucault, 1991:194). 'Development', as Gardner and Gerharz (2016) point out, is a prime example of a 'regime of truth', framing the world in a way that historically enabled the North to uphold its power over the South. However, while there are various historical manifestations of this - from predatory land grabs in the colonial era to territorial incursions in the name of 'security' - what distinguishes the modern era is the way recent neoliberal trends towards trans-nationalisation and privatisation transform the state and the particular ways in which governance is performed (Randeria, 2003). It is also important to understand that neoliberalism, as Bose (2013) points out, is a seemingly ubiquitous term, simultaneously full and empty of meaning. As Tickell and Peck (2003) argue, neoliberalism needs to be seen as a disciplinary apparatus through which market-based economic rationalities can engineer new forms of governance and subjectivity. Through concepts such as roll-back and roll-out neoliberalism, Tickell and Peck show how extensions of neoliberal ideals through the state apparatus can be reproduced in new contexts and new forms, often framed by the rhetoric of taming the worst excesses of the capitalist system while simultaneously affirming its ascendance and availability (Bose, 2013). As this volume shows, much of the contemporary land struggles in India demonstrate such newer ways in which state apparatus supports privatisation and marketbased economic rationalities. .

At a more epistemological level, Gardner and Gerharz (2016) have carefully reviewed the distinctions between the ideas behind land grab (not necessarily sudden/violent land seize, but a process that can be incremental, subject to local political trends, and even legal and orderly),

\footnotetext{
${ }^{1}$ There is an emerging body of literature on this theme. See, for example, Levien, 2013; Feldman and Geisler, 2012; Adnan, 2013; Cross, 2014.
} 
enclosures (not only acquisition of common land, but of land that is already privatised and enclosed); dispossession (to be dispossessed implies original possession, but often users/inhabitants of land do not have legal tenure); and displacement. The last one is particularly important. The term displacement arises from a literature that focuses on large-scale movements and community resettlement (Parasuraman, 1999; Cernea, 2006), thereby turning the attention from property rights and possession to emplacement, i.e. 'the social as well as economic forces that structure relationships to localities and livelihoods, and indeed the costs of forced movement' that often goes beyond the loss of land and includes loss of social protection as well (Gardner and Gerharz, 2016:7). Feldman and Geisler (2012) provide another useful distinction between in-situ and ex-situ displacement. Ex-situ displacement involves people actually leaving their land, and is therefore more prominent. However, in-situ displacement, albeit often invisible as people are not physically displaced, is no less catastrophic as it leads to a critical impairment of the means of social reproduction (as we shall see in the case of Rajarhat). In a similar vein, Gardner and Gerharz (2016) also distinguish between forced displacement (either state-led, or by other non-state agencies such as local mafia) and displacement that takes place as a result of wider urbanisation processes and commodification of land, or the long-term market processes that gradually erodes agrarian relations and livelihoods.

Most of these mechanisms are clearly at play in contemporary forms of land struggle across much of the developing nations. In India, however, what is interesting to note (but often overlooked) is how this fuzzy domain of displacement-dispossession allows traditional social forces (like caste) to reinvent and/or reassert themselves in newer forms. As this volume aptly demonstrates, the reconfiguration of caste relations as a result of contemporary land struggles and how such struggles themselves are being shaped through traditional caste-based hierarchies, are both important areas to explore. The Rajarbat story is a prime example of this. While the various theoretical constructs around land struggle give the paper its analytical grounding, the challenge is to make sense of such associated reconfigurations of social dynamics, thereby bringing 'caste' into the context of India's new land wars.

\section{The Development of Rajarhat}

West Bengal has been at the forefront of the narratives of 'land wars' in contemporary India, particularly due to the Singur-Nandigram events that had grabbed national headlines during 20062008 (see Nielsen, 2015, and Sarkar and Chowdhury, 2009 for details of Singur and Nandigram respectively). Not only did these incidents spark nationwide debates about the nature and legality of acquisition under the archaic colonial law of 1894, but also marked critical junctures in the state's political fortunes and for the Indian Left. The LF - having returned to power for an unprecedented $7^{\text {th }}$ consecutive term in 2006 - completely collapsed under the crisis that emerged from its high handedness in acquiring farmland for private entrepreneurs in these two hamlets, eventually exiting office in 2011. Rajarbat, in comparison, made sporadic headlines, and it was only in the context of Singur-Nandigram that it was discussed once again, almost a decade and half after 
its inception. Today, it remains West Bengal's 'futuristic smart city', an effort that the current TMC government remains equally committed to ${ }^{3}$.

Calcutta, the capital of West Bengal, is often characterised as 'the city that got left behind' ${ }^{4}$ Since 1977, while the LF (and particularly the CPIM) consolidated itself politically via the twin measures of land reforms and panchayati raj - along with a series of political manoeuvres that allowed the 'party' to entrench itself as a hegemonic entity in every state institution - the industrial fortunes of West Bengal had continued to dwindle. Riddled with stagnant industrialisation, gradual loss of urban political ground, and dire infrastructural conditions (Das and Mahmood, 2015), the LF took up the mantle of urban development by early 1990s, which gradually became the primary spatial catalyst in its attempt at an economic rejuvenation. The government aggressively sought to transform Calcutta into a world-class city, following the 'predictable formula of elite enclaves of residence and leisure, economic zones to attract mobile capital, and civic campaigns to insure beauty and order in the city' (Roy, 2011:259). The Calcutta new town project, located in the Rajarbat area on the north-eastern fringes of the city, was its premier programme.

Rajarbat, an area in the North 24 Parganas district, has a vibrant political history, being involved in the Salt March, Non-cooperation and Quit India movements in pre-independence India (Karmakar, 2015). It remained politically relevant post-independence as well, with local landlords orchestrating large scale land grabs from farmers by virtue of their proximity to state administration, eventually leading to the consolidation of the communist party in the area in the $1960 \mathrm{~s}^{5}$. Rajarbat had several large fish embankments or bheris, workers from which created a bheri labourers' organisation under the CPIM banner, and started to fight for better pay and ownership of land. The struggle intensified as the LF came to power in 1977, and by mid-1980s CPIM had established complete control in the area. But it was also engaged in rent-seeking activities, as profits from the bheris had to be channelised to local party units (Mukherjee, 2016). The situation changed again in the early 1990s, as the government conceived the new town project $^{6}$ : a self-contained and environment friendly new planned settlement to ease Calcutta's population pressure, and given its proximity to both Calcutta and the airport, also to be developed as a major business and IT hub (HIDCO, 1999).

As per the first land use plan (HIDCO, 1995), the total Rajarbat project area was 2750 hectares, allocation of land being as follows: 30.5\% residential, 7.3\% industrial, 5.5\% commercial, 1.1\% social/educational/healthcare facilities, $8.8 \%$ roads/transportation, and $47.6 \%$ open space. In 1999, the entire project was handed over to the West Bengal Housing and Industrial Development Corporation (HIDCO). HIDCO published a revised land use plan changing the total area to 3075 hectares, reducing open space allocation to $28 \%$, and increasing residential area to $50.6 \%$ (HIDCO, 1999). The plan was subsequently revised several times, and by 2010 the allocations were: $41.77 \%$

\footnotetext{
2 http://www.wbhidcoltd.com/org desc.php?pg=invcommon\&typ=common\&tag=aboutus com

${ }^{3}$ For example, in 2015, TMC announced the development of a business hub in Rajarhat based on London's Canary Wharf: http://aitcofficial.org/aitc/canary-wharf-model-for-business-hub-in-rajarhat/

${ }^{4}$ The Economist, $7^{\text {th }}$ January 2012, http://www.economist.com/node/21542446

${ }^{5}$ Some of the early political leaders in the area were low-caste (namasudras)

${ }^{6}$ Rajarhat was a part of the government's increasing emphasis on urban development, also reflected in other ongoing initiatives such as a the Calcutta Megacity Programme.
} 
residential, $0.23 \%$ industrial, $5 \%$ IT services, $11 \%$ commercial, $8 \%$ social facilities, $12 \%$ transportation, and 22\% open spaces (Mukherjee, 2016). ${ }^{7}$ Contrary to initial objectives, Rajarbat thus gradually emerged as not an industrial or commercial hub, but largely a residential settlement. The area is now primarily divided into Action Areas I (677 hectares), II (1310 hectares) and III (783 hectares), designed to accommodate approximately 1 million people, along with another 0.5 million floating population (HIDCO, 2012; see figure 1).

Geographically, the entire Rajarhat block amounted to an area of 107.87 sq. km, and had 47 inhabited villages, 54523 households, and a net population of 417192 (predominantly low-caste and Muslims, see Table 4) by 2001 (District Statistical Handbook, 2003). The entire block was divided into 55 mouras $^{8}, 25$ of which were initially notified for acquisition as per the Land Acquisition Act of 1894. ${ }^{9}$ Besides compensation, the government had also promised to rehabilitate all evicted families, train and give employment to at least one family member. However, most of the land was acquired for Rs. 300,000/acre, almost half the market price of Rs. 600,000 (Johnson and Chakravarty, 2013). Another estimate is that HIDCO purchased land at a rate of Rs. 5$6000 /$ kath $^{10}$ against the officially registered rate of Rs. 4-50000 (Sengupta, 2008), selling it within a year or two at Rs. 60000/katha, and at Rs. 200,000/katha (Johnson and Chakravarty, 2013).

Given the scale of the project, it is perhaps not surprising that the entire process was fraught with contradictions, the wider political connotations of which have been explored in the next section. The following, however, are only some of the key omissions in the planning-acquisition phases itself, identified in a scathing CAG (Comptroller and Auditor General of India) report (2007).

- HIDCO was to prepare a 'Detailed Development Plan' of Rajarhat within two to three years of notification. But in August 2007, after a seven year lapse, HIDCO declared that it was not aware of this requirement, thus having neither assessed the demand, nor devised a comprehensive strategic roadmap.

- Against projected acquisition of 5,400 hectares by 2006-2007, HIDCO had acquired only 2,806.04 hectares from by March 2007. This led to time-cost overruns of 48 months and Rs. 787.6 million respectively. In August 2007, HIDCO stated that it was not aware of the increase in area from 3075 to 5400 hectares, showing lack of coordination within the company itself.

- While determining the market price of 635.13 hectares of land in four mouzas, the rates were fixed two to $41 \%$ below the prevailing market rates. Consequently, 26,565 land owners were deprived of Rs. 334.5 million.

\footnotetext{
${ }^{7}$ As per HIDCO (2012), the entire planning area today stands at 9390 hectares. 6839.31 hectares have been acquired by 2012.

${ }^{8} \mathrm{~A}$ mouza is an area comprising of multiple settlements, a revenue collection unit in a pargana (revenue district).

${ }^{9}$ Eventually, 45 mouzas were notified for acquisition, of which 33 fell within the North 24 Parganas district, and 12 in the South 24 Parganas district (HIDCO, 2012).

${ }^{10} \mathrm{~A}$ katha (or kattha or cottah) is a unit of land measurement, approximately equal to 720 sq. feet or 66.89 sq. metre.
} 
- The government ignored the provisions of the national policy for rehabilitation and resettlement, constituting its own committee to determine rehabilitation modalities instead.

The nature of development in Rajarhat thus deviated significantly from what the government had originally promised. However, such planning omissions and contradictions were only at the surface. The true nature of the Rajarbat story is to be found in its politics instead: a nexus of violence, obfuscation and irregularities drawing legitimisation from the neoliberal idea of urban regeneration. It was also a process that reinforced traditional caste-hierarchies in the area, albeit in implicit forms (for e.g. the emergence of low level cartels or 'syndicates', discussed later), as there was no explicit mobilisation or discrimination along caste. The next section briefly outlines this politics, before turning to an examination of the caste angles.

\section{The Politics of Displacement}

In 1999, the government published a report titled: 'Report of the Rehabilitation and Resettlement Committee for Project Affected People of New Town Project'. It read:

A unique feature of this project [is]... a continuous dialogue between the Project Affected Persons (PAP) and the project authorities...Consent of the PAP was obtained through discussions and meetings. As a result the project has not been so far plagued with court cases and litigation...The pro-people attitude taken by the project authorities and the Govt. should be emulated in other projects requiring large-scale acquisition of land and involuntary displacement of people.

Compare this with the following excerpt from an investigative report published by The Sanhati Collective (Sengupta, 2008:4).

The CPI(M) party leadership went on a land grabbing spree with the active collusion of the local police and administration. Poor people fearful for their lives were forced to sign off their land at gunpoint...the whole area was under the grip of fear and terror....Those who were unwilling to give up their land... were subject to unmentionable strong-arm tactics. Many left hearth and home because of beatings and harassment. Those who reported to the police were murdered.

The two versions could not be more contrasting. And while the second is a rather dystopian account, tales of land grab, intimidation, and violence are not uncommon in Rajarbat. A Nagarik Mancha ${ }^{11}$ publication, for example, notes that 'land sharks became immediately active in the area. Forceful land grabbing and dispossession also escalated rapidly. Buying land in very low prices, they later sold it at much higher rates, or received compensation...More than 50 people are estimated to have been murdered in Rajarbat (Dey, 2011:6-8; translated from Bengali). Similar anecdotes, stories, and memories can still be heard aplenty if one enters the remnants of erstwhile rural settlements in the area. A few such examples have been recounted below, demonstrating how '...land [was] looted from the local villagers...the empty fields there represent[ing]...the death of

\footnotetext{
${ }^{11}$ Nagarik Mancha (citizens' platform) is a Calcutta based non-political civil society initiative.
} 
agriculture...its murder by capital, the savage commodification of land, and the resurgence of private property in the city' (Dey, Samaddar and Sen, 2013:19-20; emphasis added). Once again, it is interesting that such high levels of disruption in an area with $50 \%$ low-castes and Muslim population still did not lead to any direct caste based mobilisation, something that would have been the expected course of events in most other states.

\section{<Insert Figure 1 here>}

How is then one to make sense of this politics? There are, perhaps unsurprisingly so, a range of cross-cutting themes at work. First and foremost, the false duality of urban development (Robinson, 2002) is clearly at play, as the grand promise of a convergence of capital, people and resources in the image of a 'global city' hides the inequalities embedded in the process. The convergence of course dwells on the post-1991 economic liberalisation, but what 'neoliberalism' means in the context of Calcutta, given its Leftist character, is important to understand. Expectedly, it is something that the Indian Left has routinely criticised as the root cause of the deep distress of contemporary Indian society. And yet, while continuing with a rhetorical critique, the CPIM also adopted some of its key elements, particularly evident in its changing attitude towards industrialisation: from an erstwhile militant opposition towards private-capital to a renewed Statement on Industrial Development (1994), promising to make full use of the post1991 economic reforms (Das, 2018). The political history of West Bengal post-liberalisation has been dominated by this contradiction, also markedly evident in the strategy of 'urban developmentalism' that the CPIM/LF pursued in the 1990s, envisaging 'a broad-range of publicprivate partnerships in the provision of housing and infrastructure... marking a shift from prior policies of slum improvement to investments in the upper end of the housing market' (Roy, 2004:152). The aim was to develop urban infrastructure by encouraging foreign investment, making Calcutta a hub for new IT and service sector industries. Such a strategy, as Roy (2004:153) argues, manifests the key elements of neoliberalisation, locating the state as a site of market activity, positioning real estate development as a centrepiece of the city's productive economy, capitalising on state assets such as public land, and creating a distinct new geography. The most striking feature of this transformation was the fact that no longer were state agencies and organisations at the helm, instead, 'a complex matrix of institutional and informal linkages has taken their place. In some cases these are partnerships between government agencies and private corporations' (Bose, 2013:136). In the name of mobilising resources for rapid development, all government housing agencies and development authorities had joined hands with private investors ${ }^{12}$ to build skyscrapers, townships, IT hubs etc. Rajarbat was the most prominent and celebrated manifestation of this vision of urban developmentalism, projecting Calcutta's position and success as an entrepreneurial city by materialising its connections to the networked global economy

This is precisely where the false duality of urban development can be located. In the shadow of a celebrated, market-led urban regeneration, lay a plethora of techniques used by the state,

\footnotetext{
12 For e.g. Bengal Shrachi, Bengal Ambuja, Bengal Peerless, Bengal Greenfield, etc. are all public-private entities featuring prominently in Rajarhat. The CAG report (2007) also noted several undue favours towards two private parties, IRCON and Mackintosh Burn Ltd.
} 
party/party-controlled elements to forcibly impose a contractual exchange facilitating the interests of the political elite and investors, and marginalising the local population (the brunt of which had to be borne by the low-castes). In this sense, Rajarbat demonstrates the fuzzy terrain of neoliberalism induced displacement-dispossession, that works by multiplying regulatory sites and dominates via a series of entities that might not be always traceable back to the state (Gupta and Sharma, 2006), masking political interventions in a market language around investments and development. Additionally, and as evident in most cases of forced displacement, cycles of violence and intimidation was also critical in imposing this exchange.

\section{A History of Resistance and Violence}

To what extent is the government's claim - that acquisition in Rajarhat has largely been peaceful and coercion-free - true? It is true that the promise of creating industries did generate an initial buzz around the project, buoyant with the government's promise to give rehabilitation and employment to every evicted family. However, the situation changed soon, once it became evident how rapidly land-prices had escalated, and the absence of alternative jobs and housing. Having lost their land, the only recourse left to farmers was to work as daily wage labourers, or do odd jobs as masons, carpenters, and housemaids (for the women). This is reflected in the following tables that document the rapidly reducing farming opportunities in the area post-2000. Table 1 demonstrates the reduction in farming population from 2001-2004 when the project was at a full swing; Table 2 shows the rapid fall in the net area under cultivation from 1996 onwards; and Table 3 documents the concomitant stagnation of agricultural, manufacturing workforces and a rise in the 'other' category, which comprises of such small jobs. The 2007 CAG report noted that only 2691 individuals had been trained, along with 47 cooperative societies and 56 self-help groups set up with just 3073 landowners. In fact, 'even after a lapse of eight years, [HIDCO] had rehabilitated only 17 percent of identified project affected families... and failed to identify the remaining erstwhile landowners' (CAG, 2007:27).

\section{<Insert Tables 1, 2 and 3 here>}

The following conversations from the field research are reflective of the current condition of the majority of the population in Rajarbat. Similar accounts can be heard in almost every village.

My 7 bighas $^{13}$ of land was acquired at Rs. 8000/katha. The entire money is gone. Today, most of my family members work as carpenters, daily wage labourers. I supply computer parts to a small shop (Sabir Ali, Kochpukur village). ${ }^{14}$

The motorbike that I am riding was bought with the compensation money, the rest is gone. No one in my family has a steady income (Sajauddin Dhali, Patharghata village) ${ }^{15}$.

\footnotetext{
131 bigha $=1 / 3$ acre or 1337.9 square meters.

${ }^{14}$ Interview, $18^{\text {th }}$ April 2017, Kochpukur, Rajarhat.

15 Interview, $20^{\text {th }}$ April 2017, Patharghata, Rajarhat.
} 
I am not educated, but with whatever compensation I received, I sent my children to school. I used to farm my own land. Now I work as a labourer (Amar Mandal, Jotbhim village) $)^{16}$

My father is unemployed, my mother gets some tailoring work from the nearby apartments. We had 5-6 bighas of land, but now I drive an autorickshaw (Rakesh Mandal, Hatgachha village) ${ }^{17}$.

Alongside the lack in employment opportunities, there was a network of party cadres and local strongmen who provided 'critical means of linking system-wide scales of land acquisition with local processes of expropriation' (Johnson and Chakravarty, 2013:291). Farmers unwilling to accept acquisition notices faced increasing intimidation and brutality. Many were offered take-orleave deals, enforcing them to acquiesce lest they forfeit any claim to compensation. These 'offers' were made with a timeline of days, as opposed to the two years prescribed in the Land Acquisition Act (ibid.). The tactics were often rather innovative. For example:

CPIM enlisted local youths to put up iron poles in farmlands, paying them Rs.100 per pole. The poles were to indicate that the plots will be acquired, and cannot be sold by privately, way before acquisition notification was issued (Baur Molla, Aatghora Village). ${ }^{18}$

Small gangs started operating in every locality, known as ribbon gangs. They would wear coloured ribbons in their wrists... a specific colour earmarked for a specific locality, and directly controlled by CPIM local committee (Sheikh Nizamuddin, Aatghora Village). ${ }^{19}$

Photocopy shops were pressurised to not print/copy any pamphlet/poster related to resistance movements, a trend continuing even today (Golam Sardar, Chakpachuria Village). ${ }^{20}$

Many such anecdotes can be heard in Rajarbat even today, describing the increasing cycles of violence and resistance that marred the initial years of the project. By the late 1990s, locals had united to form the Rajarbat Jami Bachao Committee (RJBC; Save Rajarhat Land Committee), agitating against the high-handedness of the state agencies and demanding better compensation packages. This however quickly gave way to further episodes of coercion, intimidation, and violence, as 'CPIM goons were going around... forcing people to accept the [acquisition] notice at gunpoint' (Sengupta, 2008:5). Many villagers recalled instances of their signatures being forged, electricity and water connections disconnected, farmlands being destroyed by sand-filling, forced disappearances and even murder ${ }^{21}$. The entire exercise was party controlled, with barely any stateagencies present on the ground. Gautam Deb (Housing Minister of the LF and the chief architect of Rajarhat) boasts how he successfully handled the entire process with his party-people:

We conducted several party meetings, where I instructed my local party members to carry out ground-level negotiations. At times I went to Rajarbat with thousands of party-comrades, who directly dealt with the farmers. We did not even need the police (emphasis added). ${ }^{22}$

\footnotetext{
${ }^{16}$ Interview, $10^{\text {th }}$ April 2017, Jotbhim, Rajarhat.

17 Interview, $12^{\text {th }}$ April 2017, Hatgachha, Rajarhat.

18 Interview, $9^{\text {th }}$ April 2017, Aatghora, Rajarhat.

${ }^{19}$ Interview, $9^{\text {th }}$ April 2017, Aatghora, Rajarhat.

${ }^{20}$ Interview, $12^{\text {th }}$ April 2017, Chakpachuria, Rajarhat.

${ }^{21}$ Dey (2011) provides a list of 50 people who remain unaccounted for till date.

22 Interview, $20^{\text {th }}$ April 2017, Salt Lake, Calcutta.
} 
Dealing in this sense does not mean formal negotiations. Instead, it implies using locally influential party functionaries to coerce the unwilling farmers into acquiescing, sometimes through subtle/informal tactics using local familiarity, friendship, and family ties, or force and intimidation using their political clout at other times, as evident in the examples above. ${ }^{23}$ Gradually, once such incidents started to dominate media headlines, the party changed gears. Undertones of violence continued to exist, but other non-coercive modes of power were used: 'bribe everyone, co-opt all, make all the stakeholders share in the loot-and-prosper process... while keeping the directly dispossessed out. The dual strategy of inclusion and exclusion has been refined greatly to make Rajarhat possible' (Dey, Samaddar and Sen, 2013:115). A 'neighbourhood committee' was formed to informally negotiate with the farmers. Leaders of agitating farmer groups were invited to meet Rabin Mandal (local MLA till 2001) or Gautam Deb in person, but the meetings were held in the presence of the officer-in-charge of Rajarbat police station and some CPIM-sheltered local strongmen, thus implicitly reinforcing the intimidation. Another useful strategy was to bribe/coopt any opposition, for e.g. Tanmay Mandal (TMC MLA), Sukhen Chakrabarty (TMC councillor), Jaydeb Karmakar (panchayat samiti member) were all important faces of the resistance, but allegedly bought over by CPIM and made members of the neighbourhood committee. Conversely, many who did not own any land were able to use their political connections to siphon off compensation funds. Some close to CPIM top-level leadership were also major stakeholders in many real-estate projects, a prominent name being that of Arun Mahewari, husband of CPIM MP Sarala Maheswari. The overall situation was aptly summarised by a Times of India article:

A deadly cocktail [of] money, muscle power and political patronage sullied the green fields of Rajarhat. Since the early '90s, this area...was in the hands of toughs like Majid Master, Arabul Islam, Gaffar Mollah, Bulton [all noted criminals]...Suddenly, the fields of Rajarhat saw a gold rush. Land prices escalated and real estate was the new buzzword. ${ }^{24}$

In addition to the cycles of intimidation and violence, there were a number of other factors that determined the course of events, particularly the way institutional mechanisms were circumvented to aid acquisition. Three particular instances stand out.

First, the 1894 Land Acquisition Act required that a preliminary acquisition announcement has to be published in the official government gazette, on local billboards and in two local newspapers, at least one being in the regional language. The district collector must record any objection, and payments must be made within two years of the original notification. ${ }^{25}$ Now, hardly any of these were followed, and the local administration rarely made an effort to inform the villagers about the formalities. Instead, as mentioned before, offers were on take-or-leave basis, with a timeline of days (Johnson and Chakravarty, 2013). Second, and following from the above, was the implementation of Article 17 of the Act. Commonly known as the 'urgency clause', it allows foregoing of the 'objection' phase if the need for the land is urgent, which the government used to override the regular consultation/negotiation phase. However, the Article also specifies that

\footnotetext{
${ }^{23}$ This is how the CPIM used to operate on the ground, especially in rural areas. See Bhattacharyya (2016) for a detailed review.

${ }^{24}$ Times of India, $6^{\text {th }}$ September, 2009. https://timesofindia.indiatimes.com/city/kolkata/Guns-money-amarred-village-idyll/articleshow/4977149.cms

${ }^{25}$ The Act can be seen at megrevenuedm.gov.in/acts/land-aquisition-act-1894.pdf
} 
such cases of urgency must stem from actual unforeseen emergencies, natural disasters, etc., which was evidently not the case. This illegality remains completely overlooked till date. The third is a PIL (public interest litigation) filed by RJBC in the Supreme Court against HIDCO in 1999, claiming no project environmental impact assessment (EIA) was undertaken. In response, the court ruled that an EIA had been conducted only for 622 hectares, and thereby any construction/development in the remaining 3075 hectares was illegal and hence prohibited. ${ }^{26}$ However, this ruling was violated by HIDCO and all associated private developers, and RJBC filed another PIL at the Calcutta High Court. It was rejected on the ground that any prohibition would undermine the larger economic benefits of the project, the judge famously quipping that the petitioners should consider living in a cave (Dutta, 2010). It later became known that the judge was among the list of beneficiaries who had received a plot in Rajarbat directly from the urban minister. ${ }^{27}$ An associated event was the complete ignorance of the government's own 'Report on the Status of Environment in West Bengal' (GoWB, 1998), which clearly stated that: 'recent development proposal for setting up of a satellite township at Rajarhat...call for critical appraisal and year round impact assessment...East Calcutta has long been acknowledged as an ecologically fragile area... [and] should be considered as 'No Development Zone". This glaring disregard of the government's own assessment by HIDCO has remained completely ignored.

\section{The War of Development}

These narratives about the in-situ displacement in Rajarbat not only demonstrate the blow to the means of social reproduction in the area, but also indicate the workings of a certain form of governability that had become a key marker of the CPIM rule in West Bengal. Bhattacharyya (2016) calls this the 'party-society' - a form of societal hegemony that the CPIM successfully consolidated throughout its reign, where one's identity was to be derived solely from political allegiance, the party and its cadres becoming the supreme authority in the process. While it's beyond the scope of this paper to delve into the conceptual contours of party-society, what is important to observe is that how this hegemonic control of the party and the displacement it ensued in Rajarbat derived legitimacy from the notion of development as a 'regime of truth' (Foucault, 1991). The partymediated coercive/non-coercive power tactics, forced/unforced displacements, institutional obfuscation, etc., ensured that the government's promises to the disenfranchised and the ideological commitments of a Leftist regime, both remain subservient to the great transformative idea of urban developmentalism, thereby bestowing a certain degree of inevitability and acceptability on the unfortunate consequences for the sake of the greater good. This is perhaps most apparent in an observation of the Rehabilitation Report quoted in GoWB (1999:4). In describing its concern for the dispossessed, the committee made a comparison with drew the equivalence of collateral damage in military operations:

...once the compensation amount as determined...was paid...that should end the matter with regard to the PAP [project affected persons]...In India so far we have been following this

\footnotetext{
${ }^{26}$ Supreme Court Writ Petition No 7516(W), 1999.

${ }^{27}$ Many bureaucrats, prominent sports/entertainment figures, retired judges, etc. received land in Rajarhat under the discretionary '10\% Chairman's quota'. http://www.business-standard.com/article/economypolicy/rajarhat-allotments-come-out-of-closet-110122200048 1.html
} 
approach...[But] "collateral damages" as the military say when they hit civilians or "acceptable cost" are no longer tolerated.

This is an extraordinary statement. The state essentially perceives itself as pursuing a war of development, where dispossession is an unfortunate but acceptable collateral. Furthermore, and in spite of promising not to tolerate any further damages, the report goes on to claim that not all victims are equally affected owing to their 'inherent staying power ${ }^{28}$, and maintains that 'the life...of the PAPs should not be any worse [but not necessarily better] than what they were in the pre-project era. Attempts should be made to prevent...impoverishment' (ibid.). The statement not only speaks volumes about the government's attitude towards the dispossessed, but also demonstrates how neoliberalism functions as a disciplinary apparatus (Tickell and Peck, 2003), reproducing its ideals via certain forms of governance and subjectivity, even within a communist regime. This is equally evident in Gautam Deb's assertion on the economic benefits of Rajarhat, along with an almost surreal resonance of the military analogy:

Investments of this scale could impact national GDP. See how many 5-star hotels and international standard hospitals there are today. Is there any country where the government does not take land for military or war purposes? It is absurd to claim benefits beyond what the law permits. If tomorrow I build a hydrogen bomb in that land, do I have to give everyone a profit share?29

This sentiment aptly encapsulates the conundrums of the Rajarbat story, and the mind-set of those in power. In fact, the title of this volume, India's 'new land wars', could not have been more appropriately named. As war is a 'regime of truth' superseding all scrutiny, so is development. And just like in a war, it remains quite possible that despite attempts to avoid the collateral damage of impoverishment, exclusions will still occur, and that is acceptable to the agents of this war, i.e. the state and its regulators. Albeit unfortunate, collaterals are but an essential cost to pay for the greater good for which the war is supposedly being fought.

\section{Reinventing Caste Relations in Rajarhat}

Where then does caste feature in this story? On the surface, it does not. There was no caste based mobilisation in Rajarbat, nor did it ever feature in any government or media report. This is not entirely unexpected, as caste has been notoriously understudied in West Bengal, largely owing to its very distinctive political history. Neither during the early decades of Congress rule or the LF was caste a strategy of electoral mobilisation, nor has there been a major caste-based social movement in the state. Instead, the postcolonial Bengali intelligentsia has successfully constructed a nuanced class-conflict discourse, subtly excluding the notion of caste from its analytical realm. However, as Chandra and Nielsen (2012) point out, beyond aggregate election data, caste does emerge as an important indicator of popular political behaviour in the state. In fact, caste dynamics in Bengal can be both overt and covert; the obvious upper-caste dominance on one hand, and hidden, even insidious ways in which a modern caste society has flourished on the other (Chandra et al, 2015). And yet, it is undeniable that a prolonged Left hegemony has somewhat led to the

\footnotetext{
28 Possibly indicating that the poor are somehow conditioned to sustain hardships.

${ }^{29}$ Interview, $20^{\text {th }}$ April 2017, Salt Lake, Calcutta.
} 
ideological subsumption of caste by class, ostensibly underpinned by loyalties forged 'across divisions of caste and community' (Chatterjee 1997:69); and the conspicuous socio-political dominance of the self-professed 'casteless' Bengali bhadralok $k^{30}$ (Lama-Rewal, 2009).

This last notion requires some unpacking. The mainstay of Bengali communism, the bhadralok had turned to Marxism as a political creed in the 1930s (Franda, 1971; Chatterjee 1997). It was a status not ascribable but had to be achieved, where caste was supposedly not important. In reality, the bhadralok belonged overwhelmingly to the upper castes, whilst the lower castes, predominantly involved in low-paid manual jobs, were referred to as the chbotolok (low/non-respectable people). The term chbotolok also has an abusive connotation, often used by the bhadralok to denigrate one of their own caste (Roy, 2012). The embedded politics of caste-hierarchy is thus not only entrenched in the upper-caste consciousness, but beneath the radar of aggregate electoral politics, continues as a key organising principle of social lives (Chandra et al, 2015). In fact, despite the rhetorical rejection of caste by the bhadralok Marxists, the decades of Left rule has brought only a limited societal transformation as far as relevancy of caste in everyday life is concerned. Ruud (1994), for example, has shown in great detail how the local reactions to the Marxist penetration of rural Bengal were influenced by shared histories inflected by caste traditions and stereotypes, the Marxist movement failing to initiate any structural shifts in the local perceptions of power and authority.

Contextualising the Rajarbat story against such a backdrop thus faces a dual challenge. While Rajarhat has been in news in light of the recent land acquisition strife in West Bengal, the caste question has barely received any attention. And even if this is attributed to the scant historical attention towards Bengali caste politics, the unfolding of events on the ground did not follow caste lines either (see also Nielsen, this issue). Yet, it is this dichotomy that raises an intriguing dialectic. How does the salience of caste hierarchies continue to inform everyday politics and structure political action, while reproducing its own invisibility at every turn? The politics of caste in Rajarbat can shed some light on this invisible agency.

\section{The (In) visibility of Caste}

Despite a conspicuous absence from political discourses, caste remains highly visible in Rajarbat. As one enters the villages that lay ghettoised amidst the urban settlements - neatly hidden away from the view of the skyscrapers promising 'five-star luxury' and 'global living standards' - the multitude of caste relations is hard to miss. First, the population demography of the area itself is noticeable, Dalits and Muslims being the two predominant groups. In fact they were more than $50 \%$ of the entire population in 2003, and remains at around $40 \%$ as per the 2011 census data (see table 4).

\section{<Insert Table 4 here>}

\footnotetext{
${ }^{30}$ Literally meaning 'respectable people' or 'gentlemen', an elite class of regional intelligentsia unique to the Bengali-speaking area.
} 
In most villages, the spatiality of caste stands out, as there are distinct segregations between lower and upper-caste habitations. The upper caste locations are usually referred to as Bamun-para (locality of the Brahmins), or sometimes even identified by specific surnames such as Chakrabartypara or Ray-para (Chakrabarty and Ray being upper-caste surnames). The lower caste locations are relatively mixed, with people from Namasudras, Bhuimali, Bagdi and other low castes living side by side (although the Namasudra caste is most prominent, Mandal being the most common surname in the area). Interestingly, in a number of villages these areas are commonly addressed as the puronopara (the old locality), possibly indicative of the low-castes being the original inhabitants. There are some instances of specific caste-named localities, such as Bagdi-para (locality of the Bagdi caste), Sardar-para, and so on. Another name is also quite common in several villages: notun-para (the new locality). These areas are usually located at the village peripheries, are relatively new, the caste profile is fairly mixed, and the houses are mostly rented out to outsiders who work in the neighbouring apartments or offices. The religious segregation is however even starker, as the Muslim areas are very clearly demarcated, usually known as the Molla-para (locality of the Muslims, Molla being the most common Muslim surname in Rajarbat).

The following conversation with an old resident of Bamun-para in Aatghora village is very clearly indicative of these segregations. Notice how the importance of the Bamun-para is projected in relation to the nearest skyscraper.

My forefathers lived in this Bamun-para. My entire life has been spent here. Further down this road is Mandal-para [locality of the Mandals]. There is a small market after Mandal-para, the last shop being a butcher's. The Molla-para starts after that. We go up to the butcher's shop, but usually don't go beyond. The Bamun-para is right at the centre of the village though. There's a big tower only at a stone's throw. ${ }^{31}$

The spatial segregation is reinforced by a clear economic stratification. The condition of the houses in the upper-caste hamlets are distinctly different and more affluent. A typical Bamun-para house is more spacious, brightly painted, has a courtyard, a boundary wall, and is usually two-to-three storied. Houses in the lower-caste hamlets are much smaller in comparison, mostly one-storied, sparsely painted, and the localities are a lot more congested. Another noticeable difference is in the workforce pattern. In Patharghata mouza, for example, there are only a handful of upper-caste houses in the middle of the village, with at least one member in each family with a permanent job, some being government employees as well. In contrast, the rest of the villagers are mostly doing small odd jobs or are self-employed. Anecdotes aplenty can also be heard about upper-caste families having received substantial compensation as opposed to the residents in other areas, indicating that the former owned comparatively larger quantities of land.

There are several instances of covert caste-consciousness among the villagers, among which education emerged as a particularly interesting factor. While most villages have one or more primary schools that are well attended by children from all households, there is a clear distinction in the aspirational level. The following example is particularly illustrative, and similar sentiments are commonly heard. An upper-caste woman, while waiting for her son outside the school in Jatragachbi village, lamented:

\footnotetext{
${ }^{31}$ Interview, $9^{\text {th }}$ April 2017, Aatghora, Rajarhat.
} 
I want to send my son to a better school. He will have better teachers, and friends from better families. That is very important at this age. We keep reminding him how bigh a family he belongs to, how well-respected his father and grandfather are, but he might become like everyone else. ${ }^{32}$

Upon asking what she meant by 'like everyone else', her companion (also upper-caste) quipped unprompted:

Can't you see the conditions around? Can a bhadralok family live here? This is a chbotolok dominated area. ${ }^{33}$

Albeit not acerbic or animus, caste-hierarchies are therefore distinctly visible and relevant. And yet, when prompted, the common response - as heard from several groups of villagers across caste lines - is:

No, we have lived peacefully side by side for decades. Be it high caste, low caste, or Muslims, we don't have any problem with each other. ${ }^{34}$

This is undoubtedly true, but there is an important analytical distinction. Peaceful co-habitation of castes does not necessarily mean that the hierarchies have disappeared. 'Living in peace', while crucial - and particularly so in relation to frequent caste based violence in other states - can also indicate towards a certain degree of naturalisation of the hierarchies and caste-consciousness, and not disregarding it. The acknowledgement of one's 'high' status vis-á-vis the surrounding 'low' status is clearly indicative of the continued relevance of hierarchies, and it is important to recognise that the congenial acceptance of segregation does not deny it of an agency, but is an intellectual marker of the bhadralok instead. As an elderly gentleman, upon having said to live peacefully, conveyed further:

But of course we are proud of our heritage. I come from a bhadralok family. Whatever I am today, I still remember what my forefathers were. Should I not be proud to hail from such a 'high' family? It is because I am a bhadralok that I treat everyone equally. ${ }^{35}$

'Treating everyone equally' thus needs to translated as the bhadralok's gracious ability to do so, and not as 'everyone is equal'. This is one of the key dimensions of caste politics in Rajarbat, and indeed that of West Bengal. The invisibility of caste does not stem from traditional hierarchies having dissolved, but from the affirmation of being a bhadralok, as it is imperative for the bhadralok to (rhetorically) dismiss caste divisions. CPIM leaders have time and again displayed a similar duality, with comments like 'Marxists believe in dialectical materialism but are not atheists' and 'being a Brahmin besides a Marxist', making frequent headlines. ${ }^{36}$ While describing how he negotiated the relocation of a cemetery with local Muslim villagers, Gautam Deb expressed a similar sentiment, shifting from a casteless communist to defending the Brahmin's right in the same breath.

I promised the villagers a new and better cemetery elsewhere. They kept arguing that their forefathers are buried in that location, but I decided not to pay attention to such sentiments. As

\footnotetext{
${ }^{32}$ Interview, $17^{\text {th }}$ April 2017, Jatragachhi, Rajarhat.

${ }^{33}$ Ibid.

${ }^{34}$ Interviews, $8^{\text {th }}-23^{\text {rd }}$ April 2017, Aatghora, Chakpachuria, Jotbhim, Hatiara, Rajarhat.

35 Interview, $9^{\text {th }}$ April 2017, Hatiara, Rajarhat.

${ }^{36}$ In God we trust - 'The Marxist attempts to "defend the indefensible" smack of hypocrisy', The Telegraph, $24^{\text {th }}$ September 2006, https://www.telegraphindia.com/1060924/asp/opinion/story 6786237.asp
} 
communists we don't care about caste or religion. How could they stake their claim to that land just by burying their dead there? What if that land had originally belonged to a Hindu Brahmin? ${ }^{37}$

\section{Bhadralok, Borolok and Chbotolok}

So how did such caste-consciousness play out in context of the new town project? Upon conversing with the villagers, it became evident that there is a strong sense of frustration among large sections, having lost their permanent income source and not receiving the promised benefits. Such feelings are directed both towards the government, and also a section of the local elites with close proximity to CPIM. This, on the surface, plays out in more class terms: boro-lok (the big or rich people) vs gorib-lok (the poor people). The most common sentiment heard across villages being:

The boroloks had their party connections, and some made enormous profits overnight. It's only the poor whose conditions have steadily deteriorated..$^{38}$

Within a village, people are normally known to each other, and thereby the resentment towards the boroloks were specifically directed: this house here, that family there, the owner of this shop or those new buildings - are the ones that had party-connections or were party members themselves. Many such conversations in the villages took the shape of expressing frustration towards the boroloks for having exploited the system. The breakaway point from this pattern came during a conversation with Mahesh Dhali, a dispossessed farmer running a tea-stall in Patharghata:

So what they are the boroloks? It's only because they were close to the party that they became borolok overnight. But that doesn't mean they have become bhadralok. They are still the chbotolok that they always were. ${ }^{39}$

This is a rather insightful statement. Upon pursuing a similar line of questioning, several such responses were heard: a borolok for only two days can't be a bhadralok; they might have money, but they are chbotolok like us only, and so on.

So what does this borolok-chbotolok-bhadralok tripartite imply? First, it is important to recognise that the antagonism/frustration so commonly heard in Rajarbat villages - apart from lamenting the loss of livelihood - is primarily directed towards party elites and beneficiaries, and not necessarily towards the traditional upper caste bhadraloks (unless the bhadraloks themselves were party elites, which is not uncommon). There is a distinction between those who became economically affluent over the course of the project (the overnight borolok) and the traditionally or socially affluent (the bhadralok), as the higher social status of the bhadralok cannot be replaced by economic affluence alone. Even if the borolok is economically better off than the bhadralok, the latter continues to enjoy a higher social standing. There are of course those who are bhadralok as well as borolok, and they are usually well-respected. Referring to the Bamun-para residents of his village, Mahesh Dhali explained further:

\footnotetext{
37 Interview, $20^{\text {th }}$ April 2017, Salt Lake, Calcutta.

38 Interview, $10^{\text {th }}$ April 2017, Tarulia, Rajarhat.

${ }^{39}$ Interview, $20^{\text {th }}$ April 2017, Patharghata, Rajarhat.
} 
They are the bhadraloks, of course they will be borolok as well. But can one be bhadralok just by having money? Family, tradition, education - where will the chbotolok get these from?40

This is how caste-consciousness found new forms of expression in Rajarhat. Among the dispossessed, the lower-castes and the Muslims were particularly at a disadvantageous position given their lack of economic and social capital. But the project brought certain economic opportunities for those close to the party (for e.g., through 'syndicates' - see next section), and almost in every village were there groups of young men - largely low caste and Muslims - who did gain quick financial benefits from the urbanisation process. But their rapid economic affluence could not elevate them to the bhadralok status. They became borolok, but remained chbotolok at the same time, as their riches were not a substitute for heritage and tradition. Most villages in Rajarbat now have three groups of people: the upper-caste bhadralok (most of whom are also borolok), the ones who became borolok during the course of the project, and the chbotolok who continue in poverty. The Bengali political tradition ensures that the bhadralok continues to be respected for his social/cultural capital and upper-caste heritage, and even if economically stronger, the lower-caste borolok cannot escape from their chbotolok status in the absence of that heritage.

\section{The Syndicate-Raj}

Rajarhat today has become synonymous with 'syndicates', described in a recent news article as 'Calcutta's open secret of extortion rackets'. ${ }^{41}$ Syndicates are essentially low-level cartels that have gradually turned into 'businesses' offering 'services like purchase of land, supply of building materials and engagement of labourers to builders and property developers...extort[ing] money from petty shopkeepers, owners of small and medium industrial units and others' (ibid.:25). Although consolidated during the TMC government, the rise of the syndicates can be traced back to the Left period. In the absence of industrial investment and the much promised jobs, CPIM leaders decided to award a form of political compensation to the dispossessed, allocating (informal) contracts to local youth for providing construction material for all work in their locality. Gautam Deb personally oversaw the proceedings, as he describes in detail:

I made sure that the local youth got necessary financial assistance and permits for driving trucks, which I then hired them back for construction/land-filling purposes. I also instructed that HIDCO gave them all the small jobs - supplying material, building walls/fences and small pathways, planting trees, and also supplying labour if required. We adjusted the system itself in order to accommodate such ventures. ${ }^{42}$

While this could have been an innovative business model to generate employment, on the ground it turned entirely into a party-mediated exercise. The CPIM local committees were in charge of deciding whom the contracts should be awarded to in their respective areas, and in most cases contracts went to party-affiliated individuals (Johnson and Chakravarty, 2013). This also gave rise to a certain form of rent-seeking, as a share of the payments had to be paid back to local party

\footnotetext{
${ }^{40}$ Interview, 20 ${ }^{\text {th }}$ April 2017, Patharghata, Rajarhat.

${ }^{41}$ Hindustan Times, $07^{\text {th }}$ April 2016, http://www.hindustantimes.com/assembly-elections/flourishingsyndicate-raj-is-an-open-secret-in-bengal/story-WoDYZCYhnPJ6whzXahrHPJ.html

${ }^{42}$ Interview, $20^{\text {th }}$ April 2017, Salt Lake, Calcutta.
} 
elites, ensuring necessary political protection and insulation from law-enforcing agencies (Roy, 2016).

It is however during the TMC rule that the syndicates have flourished, becoming an almost indispensable political force. Before the 2016 state election, current Rajarhat TMC MLA Sabyasachi Dutta was quoted saying that he has 20,000 people working for him, a TMC 'army that keeps the syndicate machinery rolling and moonlights as the vote mafia during elections', ${ }^{43}$ and further claimed:

If there is no syndicate, 20,000 people will die of starvation, the government will fall. If I tell 20,000 people that you have to starve to death, even if 2,000 goons die among them it would be a major crisis...Defeating me is not simply difficult, it's impossible (ibid.).

A senior TMC member, on conditions of anonymity, described the scale of the problem:

Currently there are about 270 operational syndicates, with connections right up to the ministry. They broadly operate under two parallel authority umbrellas, controlled directly by two cabinet members. The daily collection of all the syndicates is more than half a million. The chief minister is aware of the problem, but given the money and people involved, it is an untouchable system. ${ }^{44}$

Although widespread, syndicates are notoriously difficult to talk to. In Rajarbat villages, everyone is aware of syndicates, but no one seems to know anyone involved. It was only after a month in the field that access could be gained, and under conditions of strict anonymity. While reluctant to divulge information about their operational structures and political linkages, the implicit caste aspects - or more specifically, the bhadralok-borolok-chbotolok dynamics - were freely discussed. Among the syndicates that could be observed, it was fairly obvious that membership was largely drawn from lower-castes and Muslim youth. This is perhaps not surprising given the overall demography of Rajarhat, but so is the leadership. There are two local leaders - 'Bhajai Sardar' and 'Aftabuddin' - each controlling roughly 135 syndicates, the former a low-caste Hindu, the latter a Muslim.

The obvious financial opportunities aside, what else motivates a youth to join a syndicate? The leader of a small syndicate explained:

Of course there's the money. But more important is ijjat (respect). We had no ijjat in the village. We were born chbotolok, and would have remained so had it not been for the syndicate. Today I have 12 people working for me, I have political connections. Even village elders talk to me with respect. ${ }^{45}$

Similar sentiments were echoed by several syndicate members. A relatively new and young recruit of a big syndicate, sitting in a seedy dance bar, admitted:

I have only studied till $8^{\text {th }}$ standard. There was no steady income in the family. My brother drives an autorickshaw. But now I have a good lifestyle. I will also have connections and meet important people. No one will look down on me anymore. ${ }^{46}$

\footnotetext{
${ }^{43}$ The Telegraph, 23 ${ }^{\text {rd }}$ April 2016, https://www.telegraphindia.com/1160423/isp/calcutta/story 81739.jsp

${ }^{44}$ Interview, $21^{\text {st }}$ April 2017, Calcutta.

45 Interview, $30^{\text {th }}$ April 2017, Rajarhat.

${ }^{46}$ Interview, $1^{\text {st }}$ May 2017, Aatghora, Rajarhat.
} 
Alongside quick money, it is the search for ijjat, a quintessential search for the low-castes, which seems to be the main attraction for young men to join syndicates. The most insightful comment came however from not a syndicate member, but from one's mother. Upon asking why she allowed her son to join an illegal business, she responded:

What has the law done for us? They gave us a pittance in the name of compensation, and now our land is worth millions. We can never be like those bhadralok living in our land, but if my son earns money, we can escape a chbotolok's life. ${ }^{47}$

Thus we return to the tripartite again. Besides quick money and an exciting lifestyle, the syndicateraj (as it is referred to in the media, the syndicates being the real power-brokers locally) seems to have provided an avenue for the aspirations of the lower-castes, be it for respect, or at least to escape the entrapments of being a chhotolok. The upper-caste bhadralok heritage will remain elusive for most, but at least they can climb the social ladder somewhat and be a borolok.

A final point needs to be made here. As Chandra et al (2015:7-8) point out, there has been a growing sense in recent years that something radically new is underway with caste politics in West Bengal. In contrast to her 'secular' communist counterparts, TMC leader Mamata Banerjee has no scruples about appealing overtly to caste and communal sentiments. Her 'post-bhadralok' style of politics has, in turn, opened up new spaces for articulating a plurality of communal identities in political forums. The recent prominence of Muslims and low-caste groups like the Matuas as determinant categories in the electoral politics of the state being cases in point (Sinharay, 2012). The TMC, as Chandra et al further argue, 'may be capable of denting bhadralok hegemony by effecting a genuine transformation in the social composition of political leadership' (2015:8). The prominence of the Rajarbat syndicates and its irreplaceability for the current regime could very well be a reassertion of such caste dynamics in Bengal politics. At the very least, it certainly marks a breakaway point from the bhadralok-hegemony in a post-communist West Bengal.

\section{Conclusion}

The multiple narratives around Rajarhat symbolise a new kind of realism in the politics of neoliberal India. As the old politics of citizenship withers away, a new politics is produced via the interaction of a ubiquitous neoliberal space with its collateral, the multitude of dispossessed and disenfranchised. In Rajarbat, as Sengupta, Samaddar and Sen (2013) observe, the dispossessed cannot look to this new space with desire, but they cannot leave it either. There remains the memory of a place, but there is nothing in the present real place that one identifies with, the dispossession thus not only being from economic means, but also from identity. Ranjit Nashkar, an elderly inhabitant of Patharghata, evocatively recalled:

I used to live in Patharghata, went to school in Kochpukur, and used to play in that field next to the Talpukur pond. But no one recognises these names anymore. Instead, I am a resident of Action Area II. They have erased my existence, my identity, and also that of my forefathers. Not only is my land gone, but so are my memories. ${ }^{48}$

\footnotetext{
47 Interview, $1^{\text {st }}$ May 2017, Mahishbathan, Rajarhat.

48 Interview, 22nd April 2017, Patharghata, Rajarhat.
} 
The role of the state in enacting this transformation, and the concomitant displacement and marginalisation also defines this politics. Rajarbat in this sense is a microcosm of such trends across India, and indeed across the Global South. Displacement is 'constructed' by the state, its institutions, political entities, local actors and networks, while drawing legitimacy from multiple regimes of truth - development, market, and legality. The politics thus needs to be looked for in this process of construction and legitimisation, and in the relation between what it produces and leaves behind. The space exists simultaneously in both, the politics being a product of its duality.

The caste perspective, as offered in this narrative, symbolises this dualism. On the one hand it adds to the debate on the relevance of caste consciousness in a bhadralok dominated Bengali society. As Chatterjee (1997:83-86) rightly notes, in the 'apparently uninstitutionalised world of what may be called politics among the people', caste categories provide many of the basic signifying terms through which collective identities and social relations are still perceived. On the other hand, it also demonstrates that while hierarchical caste practices might have been declining in an increasingly urban society, caste can simultaneously be reinvented and redeployed as an identity, a marker of culture, memory, heritage, and even aspiration. Caste-consciousness therefore does not disappear with increasing urbanisation, but often reinforces new forms of stratification instead. The duality of the politics, in this sense, is in the way the modern (the globalised urban economy) cohabits with the traditional (the social hierarchies), and is legitimised by it.

It is this cohabitation and legitimisation that symbolises not only the core conflict of Rajarbat, but also that of contemporary land wars in India. The unique nature of West Bengal - the political stability of the LF as well as the domination of the casteless bhadralok - does make it a rather special case among the chaotic democracy of India. But what the Rajarbat story also demonstrates in a broader sense is the continuing relevance of caste dynamics in shaping both the resistance and outcomes of land wars in newer forms: the economic stratification induced by displacementdispossession often reinforcing the traditional social hierarchies where the upper caste with social and economic capital emerges as the primary beneficiary of 'development'. In Rajarhat, the assertion on achieving the bhadralok status, or at least a borolok, is rooted in an economic dispossession that has reasserted the social entrapments of being a chbotolok. Robbed of their legitimate socio-economic relations of production on the one hand and their memories and identity on the other, the chbotolok is now in a perpetual search for both sustenance and ijjat (respect). Elsewhere, as this volume demonstrates, the search might take different forms, or caste identities can be a fulcrum around which struggle for land gets coalesced, but the nature of the conflict remains similar, a conflict where 'development' ' modernisation' reinvents or at times even reinforces traditional social hierarchies.

\section{Acknowledgement}

Vrinda Aggarwal, Sabir Ahmed, Zaad Mahmood, Ranjit Nashkar, Ranjita Neogi, Suparna Pathak, Nirbed Ray, Tejas Singh, Calcutta Mahanirban Research Group, Bureau of Applied Economic and Statistics-GoWB. 


\section{References}

Akram-Lodhi, H. (2012). 'Contextualizing Land Grabbing: Contemporary Land Deals, the Global Subsistence Crisis and the World Food System', Canadian Journal of Development Studies, 33(2), 119_ 42.

(2009). 'Modernising Subordination? A South Asian Perspective on the World Development Report 2008: Agriculture for Development', Journal of Peasant Studies, 36(3), 611-19.

(2007). 'Land, Markets and Neoliberal Enclosure: An Agrarian Political Economy Perspective', Third World Quarterly, 28(8), 1437-56.

Adnan, S. (2016). 'Alienation in Neoliberal India and Bangladesh: Diversity of Mechanisms and Theoretical Implications', South Asia Multidisciplinary Academic Journal [Online], 13, http://samaj.revues.org/4130.

. (2015) 'Primitive Accumulation and the "Transition to Capitalism" in Neoliberal India: Mechanisms, Resistance and the Persistance of Self-employed Labour', in Barbara Harriss-White \& Judith Heyer (eds.), Indian Captialism in Development, London \& New York: Routledge, 23-54.

(2013). 'Land Grabs and Primitive Accumulation in Deltaic Bangladesh: Interactions between Neoliberal Globalization, State Interventions, Power Relations and Peasant Resistance', Journal of Peasant Studies, 40(1), 87-128.

Bandyopadhyay, S. (2012). 'Caste and Politics in Bengal', Economic and Political Weekly, Vol 47(50), $71-73$.

Banerjee, M. (2015). 'Forward', in Uday Chandra, Geir Heierstad and Kenneth Bo Nielsen (ed.) The Politics of Caste in West Bengal, Oxford: Routledge.

. (2010). 'Leadership and Political Work', in Pamela Price and Arild Ruud (ed.) Power and Influence in India: Bosses, Lords, and Captains, New Delhi:Routledge, 20-43.

Bedi, H. (2015). 'Judicial Justice for Special Economic Zone Land Resistance', Journal of Contemporary Asia 45(4), 596-617.

Bhattacharyya, D. (2016). Government as Practice: Democratic Left in a Transforming India. New Delhi: Cambridge University Press.

Bose, P. (2013). 'Bourgeoisie Environmentalism, Leftist Development and Neoliberal Urbanism in the City of Joy', in Tony Roshan Samara, Shenjing He, Guo Chen (ed.) Locating Right to the City in the Global South, Oxford: Routledge. 
CAG. (2007). Performance Reviews Relating to Government Companies: West Bengal Housing Infrastructure Development Organisation Ltd., http://www.cag.gov.in/sites/default/files/old reports/state/West Bengal/2007/Commercial/ com chap 2.pdf

Cernea, M. (2016). 'Foreword: State Legislation Facing Involuntary Resettlement: Comparing the Thinking in China and India on Development-Displacement', in F. Padovani (ed.), Developmentinduced Displacement in India and China: a Comparative Look at the Burdens of Growth, Lanham: Lexington Books, vii-lii.

(2006). 'Re-examining "Displacement": A Redefinition of Concepts in Development and Conservation Policies', Social Change, 36(1), 8-35.

Chandra, U, Heierstad, G., and Nielsen, K.B. (2015) (ed.). The Politics of Caste in West Bengal, Oxford: Routledge.

Chandra, U, and Nielsen, K.B. (2012). 'The Importance of Caste in Bengal', Economic and Political Weekly, Vol 47(44), 59-61.

Chen, X., Wang, L., and Kundu, R. (2009). 'Localizing the Production of Global Cities: A Comparison of New Town Developments Around Shanghai and Kolkata', City \& Community 8(4), 433-465.

Chatterjee, P. (1997). The Present History of West Bengal: Essays in Political Criticism, New Delhi: Oxford University Press. 47(50), 69-70.

(2012). 'Historicising Caste in Bengal Politics', Economic and Political Weekly, Vol

Cross, J. (2014). Dream Zones: Anticipating Capitalism and Development in India, London: Pluto Press.

Das, R. (2018). Neoliberalism and the Transforming Indian Left: A Contradictory Manifesto. Oxford: Routledge.

Das, R., and Mahmood, Z. (2015). 'Contradictions, Negotiations and Reform: The Story of Left Policy Transition in West Bengal', Journal of South Asian Development, 10(2), 199-299.

Dey. P. (2011). Sarkar Jokhon Luthera, Kolkata: Nagarik Mancha Publications.

Dey, I., Samaddar, R., and Sen, S. (2013). Beyond Kolkata: Rajarbat and the Dystopia of Urban Imagination. New Delhi: Routledge.

District Statistical Handbook (1996-2004). 'North 24-Parganas'. Ministry of Statistics and Programme Implementation, GoWB.

Dutta, N. (ed.) (2010). Rajarbate Jomi Dakatir Itihash, Save Rajarhat Land Committee Publication, Calcutta. 
Feldman, S., and Geisler, C. (2012). 'Land Expropriation and Displacement in Bangladesh', Journal of Peasant Studies, 39(3-4), 971-93.

Foucault, M. (1991). Discipline and Punish: the Birth of a Prison. London, Penguin.

Franda, M. (1971). Radical Politics in West Bengal. Cambridge, MA: The MIT Press.

Gardner, K., and Gerharz, E. (2016). 'Land, 'Development' and 'Security' in Bangladesh and India: An Introduction', South Asia Multidisciplinary Academic Journal [Online], 13, URL: http://samaj.revues.org/4141.

Gardner, K, Ahmed, Z, Bashir, F., and Rana, M. (2012). 'Elusive Partnerships: Gas Extraction and CSR in Bangladesh', Resources Policy, 37(2), 168-74.

Government of West Bengal (GoWB). (1999). Report on the Rebabilitation and Resettlement Committee for Project Affected People of New Town Project, http://www.wbhidcoltd.com/uploads/reports/report5.pdf.

(1998). Report on the Status of Environment in West Bengal. West Bengal Pollution Control Board, Calcutta.

Gupta, A., and Sharma, A. (2006). 'Globalization and Postcolonial States', Current Anthropology, $47(2), 277-307$.

Hall, D. (2013). 'Primitive Accumulation, Accumulation by Dispossession and the Global Land Grab', Third World Quarterly, 34(9), 1582-604.

Harvey, D (2003). The New Imperialism, Oxford: Oxford University Press.

HIDCO (1995). New Town at Rajarhat: Task Force Project Report. GoWB. (1999). Land Use and Development Control Plan, GoWB.

(2012). Land Use and Development Control Plan for New Town Planning Area, GoWB, http://www.wbhidcoltd.com/uploads/reports/report11.pdf.

Johnson, C. and Chakravarty, A. (2013). 'Re-thinking the Role of Compensation in Urban Land Acquisition: Empirical Evidence from South Asia', Land (2), 278-303.

Karmakar, J. (2015). 'Encountering the Reality of the Planning Process in Peri Urban Areas of Kolkata: Case Study of Rajarhat, Archives of Applied Science Research, 7(5), 129-138.

Khan, M.H. (2004). 'Power, Property Rights and the Issue of Land Reform: A General Case Illustrated with Reference to Bangladesh', Journal of Agrarian Change, 4(1-2), 73-106. 
Lama-Rewal, S.T. (2009). 'The Resilient Bhadralok: A Profile of the West Bengal MLAs', in Christophe Jaffrelot and Sanjay Kumar (eds), Rise of the Plebeians? The Changing Face of Indian Legislative Assemblies, New Delhi: Routledge. 361-92.

Levien, M. (2013) 'Regimes of Dispossession: From Steel Towns to Special Economic Zones', Development and Change, 44(2), 381-407.

(2012) 'The Land Question: Special Economic Zones and the Political Economy of Dispossession in India', Journal of Peasant Studies, 39(3-4), 933-69.

Mahadevia, D. (ed.) 2008. Inside the Transforming Urban Asia-Processes, Policies and Public Actions. New Delhi: Concept.

Makki, F. (2014). 'Development by Dispossession: Terra Nullius and the Social-Ecology of New Enclosures in Ethiopia', Rural Sociology, 79(1), 79-103.

Marx, K. (1976) Capital: A Critique of Political Economy (Vol. 1) (Ben Fowkes, Trans.), London: Penguin.

Mukherjee, A. (2016). Villages in the City: Trajectories of Urbanisation in Rajarbat-New Town, Kolkata, MPhil Thesis, School of Habitat Studies, Tata Institute of Social Sciences. http://dspace.tiss.edu/jspui/handle/1/7463.

Münster, D., and Münster, U. (2012). 'Consuming the Forest in an Environment of Crisis: Nature Tourism, Forest Conservation and Neoliberal Agriculture in South India', Development and Change, 43(1), 205-27.

Nielsen, K.B. (2018). Land Dispossession and Everyday Politics in Rural Eastern India, NY: Anthem.

. (2015). 'Law and Larai: The (De)Judicialisation of Subaltern Resistance in West Bengal', Journal of Contemporary Asia, 45(4), 618-639.

Nielsen, K.B. and Oskarsson, P. (2017) (eds.). Industrialising Rural India: Land, Policy and Resistance, Oxford: Routledge.

Padel, F., and Das, S. (2010). Out of This Earth: East India Adivasis and the Aluminium Cartel, New Delhi: Orient Blackswan.

Parasuraman, S. (1999). The Development Dilemma: Displacement in India, Macmillan Press Ltd.

Randeria, S. (2003). 'Cunning States and Unaccountable International Institutions: Legal Plurality, Social Movements and Rights of Local Communities to Common Property Resources', European Journal of Sociology, 44(1), 27-60.

Robinson, J. (2002). 'Global and World Cities: A View from off the Map', International Journal of Urban and Regional, Research 26, 531-554. 
Roy, A. (2011). 'The Blockade of the World-Class City: Dialectical Images of Indian Urbanism', in Ananya Roy and Aihwa Ong (eds.), Worlding Cities: Asian Experiments and the Art of Being Global. Malden, MA: Wiley-Blackwell, 259-278.

(2005). "Urban Informality: Toward an Epistemology of Planning," Journal of the American Planning Association 71, 147-158.

-------- (2004). 'The Gentleman's City: Urban Informality in the Calcutta of New Communism', in Ananya Roy and Nezar AlSayyad (eds.), Urban Informality: Transnational Perspectives from the Middle East, Latin America, and South Asia. Lanham, MD: Lexington Books, 147-170.

(2002). City Requiem, Calcutta: Gender and the Politics of Poverty. Minneapolis, MN: University of Minnesota Press.

Roy, D (2012). 'Caste and Power: An Ethnography in West Bengal', Modern Asian Studies 46(04), 947-974.

Roy, R. (2016). 'Nothing Succeeds like Success in West Bengal', Economic and Political Weekly, Vol 51(22), 24-26.

Ruud, A.E. (1994). 'Land and Power: The Marxist Conquest of Rural Bengal', Modern Asian Studies, 28(2), 357-80.

Sarkar, T., and Chowdhury, S. (2009). 'The Meaning of Nandigram: Corporate Land Invasion, People's Power, and the Left in India', Focaal-European Journal of Anthropology, (54), 73-88.

Samaddar, R. (2013). 'Whatever has happened to Caste in West Bengal?' Economic and Political Weekly, Vol 48(36), 77-79.

Sassen, S. (2006). Denationalization: Territory, Authority and Rights. Princeton, NJ: Princeton University Press.

Sengupta, S. (2008). A History of the Brutal Rajarbat Land Acquisition, Bengal's New IT Hub. The Sanhati Collective. http://sanhati.com/excerpted/945/.

Sinharay, P (2012). 'A New Politics of Caste', Economic and Political Weekly, Vol 47(34), 26-27.

Tickell, A., and Peck, J. (2003). 'Making Global Rules: Globalization or Neoliberalization?' in J. Peck and H. Yeung (eds) Remaking the Global Economy: Economic-Geographical Perspectives, London: Sage, 163-81. 